\title{
Environmental Concern in the Vedās
}

\author{
Iti Chattopadhyay \\ Assistant ProfessorDeptt. Of PhilosophyRaiganj UniversityRaiganj, Uttar Dinajpur, India.
}

\begin{abstract}
In recent times, one of the major and serious problems the entire world is witnessing is environmental degradation such as ozone layer depletion, global warming and loss of biodiversity. Cutting trees randomly, polluting air, water and soil whimsically, killing non-human animals mercilessly and unnecessarily and using the natural resources excessively have become natural and regular phenomena that have brought the threat to annihilation of all living beings on earth because trees, water, air, soil and other natural resources are fundamental requirements for survival of all forms of life. To get rid of this alarming crisis, scientists, theologians, ethicists and social activists are looking for ways and means. In fact, we find that the last two decades have witnessed many treaties, summits, conventions and protocols in order to protect and conserve the whole environment. But if we go back to the ancient ages, we find that the Sacred Texts of almost all major religions of the world contain the messages of environmental protection and its conservation. They advocate that the abuse and exploitation of nature for our selfish interest is unjust and unethical. We can find many examples of moral teachings in the Sacred Texts of various religions that shed light on the caring of environment. This paper will attempt to explore the environmental awareness in the Vedās, the Principal Sacred Texts of Hinduism.
\end{abstract}

Keywords: Environmental Problem, Ozone Layer Depletion, Global Warming, Loss of Biodiversity, Sacred Texts, Hinduism, Vedās.

\section{INTRODUCTION:}

The term 'environment' generally means 'the aggregate of circumstances surrounding organisms or group of organisms including the social and cultural conditions affecting the nature of individual or community.' According to the Environment (Protection) Act, 1986, 'Environment includes water air and land and the inter-relationship which exists among and between water, air and land and human beings, other living creatures, plants, microorganisms and property" Oxford English Dictionary defines environment as "the surroundings or conditions in which a person, animal or plant lives or operates."

Hinduism is one of the oldest and the third largest religions of the world that showed profound respect and reverence for the environment including the nature from its inception. Hinduism has many Sacred Texts and almost all of them contain the insights to sustain the whole environment, both biotic and a-biotic. We find the Vedās, the Primary Sacred Tests of Hinduism and the ancient Indian treasure trove of knowledge are replete with hymns suggesting and advocating the importance and necessity of various natural resources. Especially the Vedās are chiefly concerned with the concept of nature and life and one of the chief tasks of the Vedās is natureworship. In fact, they contained huge references on environmental protection and its conservation and ecological balance. Thus, the Vedās are very much careful about the environment.

2. Four physical elements of the environment:

In fact, the Vedās attribute divinity to nature. We notice four physical elements namely earth, water, fire and air -that constitute the environment and provide the bases of life, are considered Sacred entities and thereby worshipped as God or Goddess by the Vedic sages.

2.1 Earth:

In the Vedās, we find everything related with earth and thus earth is praised and revered as mother Goddess who feeds and provides shelters everyone both biotic and a-biotic. Earth is known as Bhumi, Prithvi, Vasudha, Vasundhara and Avni. ${ }^{2}$ The earth is exhibited as a bearer of profound happiness and thus one should use it with considerable care in order to obtain such happiness The Vedās also informed us that earth and heaven combine together in order to bring rain water that is pre-requisite for survival of all kinds of life. The Prithvi Sūkta of the Atharva Veda declared: "Bhomi mata putroham prithivyah.", i.e., earth is my mother and I am her son. In it we find, emphasis is given on the productive aspect of the earth needed for the growth and maintenance of the whole biotic world. The verse goes as:

'Whose, the earth's [are] the four quarters; on whom food, plowings, came into being; who bears manifold what breathes, what stirs- let that earth (bhumi) set us among kine, also in inexhaustibleness"3 
Thus, as we are depended on earth for our basic requirements, we should protect her. In the following verse, one may notice this message.

'What of thee, O earth (bhumi), I dig out, let that quickly grow over; let me not hit (arpay)

thy vitals nor thy heart, $\mathrm{O}$ cleansing one. ${ }^{4}$

\subsection{Water:}

The Vedic sages knew the significance of water as an important part of environment. Water is depicted as the source of living beings and thus is regarded as Varuna Deva. People were ordained to worship rivers with love and affection. In the Rg Veda, it is said that pure water has the several properties viz. cold to touch, clean, purifier, tasteful, transparent and light weight. The following verse expresses the concern for water."Waters, you are the ones who bring us the life force. Help us to find nourishment so that we may look upon great joy." 5

The Prthivi Sūkta of the AtharvanVeda too expresses concern for the purification of water. "Let cleansed (cuddha) waters flow for our body; what mucus (syedu) is ours, that we deposit on him we love not (apriya); with apurifier (pavitra), O earth, do I purify myself."6

This verse reflects deep concern for pure water for environmental stewardship. 2.3 Fire:

Fire is considered as the principle of life and worshipped as Agni Deva. ${ }^{7}$ The Vedic sages knew very well that the sun is the main source of energy and thus worshipped fire which represents the energy of the sun. In the Rig Veda, fire is worshiped as the source of richness:"Through Agni one may win wealth, and growth from day to day, glorious and most abounding in heroic sons." 8

2.4 Air:

Air was worshipped as Vayu Deva. The Rg Veda addressed air as father and protector because the Vedic sages knew that air is the vital for all forms of life. In the like manner, the Rg Veda regarded air as the soul of god and human beings. The verse goes as:"The breath of the gods, the embryo of the world, this god wanders as he wishes.Only his sounds are heard, not his form. To him, to the Wind, we would do honor with our oblation." In the Shatapatha Brahmana, it is stated that "Sun and rest of the universe is woven in a string, and the string is vayu." "In answering a question asked by a student about what binds the universe together, sage Yajnavalkya said: "By air indeed, o Gautama, as thread, this world, the other world, and all beings are held together".In fact, the necessity and usefulness of the four elements viz., earth, water, air and fire are vividly exhibited in the following way:"When the clouds cultivate the earth with its water; then winds are blown, lighting is struck, vegetation comes to life and grows, sky pours the raindrop and the earth then gets ready for the welfare of the world." 11 One can notice that this whole process is admitted by modern science. Yajur Veda says: "Do not disturb the sky and do not poison the atmosphere." ${ }^{12}$. Forests and Plants:Forests and plants which are an integral parts of ecology, considered as living beings by the Vedās. Hence, they attached great importance to them. Modern science also confirmed this Vedic observation as true. In ancient times, forests were regarded as Sacred. There are number of verses in the Vedās, where we find forests and plants are worshiped in order to sustain the environment. In the Rg Veda, concern for forest, which is the habitat as well as essential for ecological balances, is found in the reverence for Aranyāni Devi who is worshipped as the deity of the forest. In the Rg Veda, it is stated:"Rejoice o plants since you are blooming and fruitful. Like victorious mares, the sprouts deliver."13

The Vedās were also conscious about the importance of the plants in the process of photosynthesis as exemplified in the following verse: 'The herbs and plants having union with sun rays provide congenial atmosphere for the life to survive, 14

If we go through the Vedās, we notice it contains many verses which have focussed primarily on the science of medicine and suggested that plants and herbs have the capacity to destroy poisons. The plants 'penetrate and get diffused into all limbs and joints of the sick'; thus rejuvenating the sick and making them healthy and happy. ${ }^{15}$ Prayer is found in the Atharva Veda in order to protect forest which is part and parcel of environment.

In the Vedic period, Vanamahotsab, festival of tree was being celebrated as a ritual to show the importance and appreciation for the selfless services provided by the trees. Protection of trees is also there in the Yajur Veda which announced: "He who rears the trees by erecting barriers round them.......conduces to our happiness". ${ }^{16}$ In fact, the Vedās identified many plants such as tulsi, peepal, rudraksha, bar and the like as useful to health and thus regarded them as Sacred. Science also agreed with Vedic conception and confirmed that peepal tree releases oxygen continuously and tulsi is a medicinal plant. It is hepato-protective, anti-microbial, anti-inflammatory, neuro-protective, radio-protective, mosquito repellent etc. 4. Animals:In the Vedās, we find care and protection towards animals also. Yajur Veda says we should not kill animals which are beneficial to all. Kings are ordained not to kill bullocks which help in agriculture and cows which give milk. Punishment has to be meted out to those who harm such helpful animals. The verse goes as: 'O King you should never kill animals like bullocks useful in agriculture or like cows which gives us milk and all other helpful animals and must punish those who kill or do harm to such animals. ${ }^{17}$ There are innumerable verses in the Yajur Veda that extended care and protection to the birds and animals acknowledging their importance to the environment. The

DOI: 10.9790/0837-2206042123 $\quad$ www.iosrjournals.org $\quad 22 \mid$ Page


following verse bears the truth:"Rhinoceros serves all warriors in preparing their shield; the Black Dog, the long-eared Ass. The Hyenas are used for protection against the demons; the Boar is for the king who wants to tear asunder his enemies; the Lion is swift like air; the Chameleon, the Peppaka, the Vultures are used for making arrows; the spotted Antelope is used for preparing mrigshalas for the learned people.",18

5. Conservation Principle:

The Atharva Veda frames conservation principles which we find in the following verse:"Let thy hills and snowy mountains, let thy forest-land, O earth, be pleasant; upon the brown, black, red, all-formed, fixed earth, the earth guarded by Indra- I, unharassed, unsmitten, unwounded, have stood upon the earth."19

6. Utilization and Regeneration Principle:

Another verse from the Atharva Veda shows how to use and regenerate the natural resource. The verse goes as:

"What of thee, O earth, I dig out, let that quickly grow over; let me not hit thy vitals nor thy heart, O cleansing one." 20

\section{CONCLUSION:}

Thus, we find that the attitude of the Vedās is holistic. Not only human beings, they attached great importance to the air, fire, water, land, flora and fauna in order to protect, preserve and nourish the environment. Man is considered as a member of this vast family. In fact, here man is taught to live in harmony with nature and recognize that divinity prevails in all elements including plants and animals that help to combat social as well as environmental problems. Thus, the Vedic perspective and belief system about both the living and nonliving elements can act as a safeguard for environmental protection.

\section{REFERENCES:}

[1] A.R. Panchamukhi, Socio-economic Ideas in Ancient Indian Literature (Delhi: Rashtriya Sanskrit Sansthan, , 1998) 467.

[2] Vasudha narayana, 'Water, Wood and Wisdom: Ecological Perspectives from the Hindu Traditions', 179-206, http://www.amacad.org/multimedia/pdfs/publications/daedalus/fall2001/01_fall_daedalus_Narayana.pdf $>$, p.183.

[3] Atharva Veda 12.1.4, William Dwight Whitney (tran) and Charles Rockwell Lanman (ed.); AtharvaVeda-Samhita, $2^{\text {nd }}$ half, Books VIII to XIX; (Delhi: Motilal Banarsidass private Ltd.,2011), 661

[4] Ibid.12.1.35, p. 667

[5] Rg Veda 10.9.1, Stephanie W. Jamison and Joel P. Brereton (trans), The Rigveda: The Earliest Religious Poetry of India,(Oxford: Oxford univ. Press, 2014)

[6] Atharva Veda 12/1/30, William Dwight Whitney (tran) and Charles Rockwell Lanman (ed.) op cit., p.666

[7] $7 \mathrm{Rg}$ Veda 10/79/1; 6/9/4; 6/4/2, Stephanie W. Jamison and Joel P. Brereton , op. cit., PP.1511, 783, 777

[8] $\quad \operatorname{Rg}$ Veda 1/1/3, ibid., p89.

[9] Rg Veda: 10: 168: 4, ibid., p.1649.

[10] 10.Shashi Tiwari, Origin of Environmental Science from Vedas, p. 163

[11] Rg Veda, 5:83:4, Stephanie W. Jamison and Joel P. Brereton , op. cit., p. 766.

[12] Yajur Veda. 5:43, Ralph T.H. Griffith (Trans), The Texts of The White Yajur Veda ,(Benares: E.J. Lazarus And Co., 1899) 43.

[13] Rg Veda. X.97.3, Stephanie W. Jamison and Joel P. Brereton, op. cit., p.1553

[14] Atharva Veda. 5.28.5, William Dwight Whitney (tran) and Charles Rockwell Lanman (ed.), AtharvaVeda- Samhita, $2^{\text {nd }}$ half, Books VIII to XIX; (Delhi: Motilal Banarsidass private Ltd.,2011)272

[15] Rg Veda. X: 97: 2-15 ,Stephanie W. Jamison and Joel P. Brereton, op. cit., p.1553

[16] Yajur Veda: 20.45, Griffith, op. cit. P. 191

[17] Yajur Veda. 13:49, ibid., p. 121

[18] Yajur Veda24:40, ibid., p.223

[19] Atharva Veda: 12.1.11, William Dwight Whitney (tran) and Charles Rockwell Lanman (ed.) 663

[20] Atharva Veda ,12.1.35, ibid., p. 667. 